\section{THE LATE INQUEST ON ALFRED RICHARDSON.}

To the Governors and Friends of the Royal Free Hospital.

The Committce of Management of the Royal Free Hospital consider it to be their duty to place before the Governors the following brief statement relative to the inquest on the body of Alfred Richardson. As the Governors are aware, the verdict affected the professional conduct of two of the surgeons attached to the institution.

With respect to one of those gentlemen, the Committee have merely to remark, that he was in nowise responsible for the operation which furnished the ground of the inquest; and that the attempt to implicate him by the verdict of the jury simply proves the amount of prejudice which existed in the case, and to which the Committee will presently more particularly refer.

The other gentleman noticed in the verdict (Mr. Cooke) was the actual operator. The operation was lithotomy. The patient was a boy, three years of age. The operation was unsuecessful. The verdict imputed its failure to a want of skill. Mr. Cooke, with a high feeling which the Committee are convinced will be appreciated by every governor, placed his resignation in their hands. But the Committee, remembering Mr. Cooke's testimonials, and his long and tried services in the hospital; considering that for more than ten years he had been actively engaged under their constant observation; that during the whole of that time, not only had no want of care or of ability ever been laid to his charge, but that, on the contrary, he had uniformly proved himself a most humane and efficient officer; considering further, that, according to professional testimony of the greatest weight, the misadventure which in this instance befel Mr. Cooke has happened many times in the hands of surgeons of the highest standing in the profession, have deemed it to be their solemn and bounden duty, as well towards the Hospital as towards the medical profession and the public, to request Mr. Cooke to withdraw his resignation, and continue one of your surgeons. And in so doing the Committee feel confident of securing the hearty approval of the Governors of the Charity.

Charges were made at the inquest, which, if true, would in culpate the general management of the Hospital; and to which, although they were entirely refuted, the Committee would re. quest your particular attention.

It was stated by counsel that the patient was under the operation for an hour and forty minutes; whereas it was distinctly proved by evidence on oath that not more than fifty minutes elapsed from the child being taken to the surgeons until it was returned and placed in bed, and that at least fifteen minutes of that time were occupied in administering chloroform and restoring the patient, so that the actual operation did not exceed thirty-five minutes, (not a very unusual period in difficult cases;) and that during that time the patient was under the influence of chloroform.

It was said, that after the operation the unfortunate child was neglected by the medical officers, and treated by the nurse with revolting brutality.

It was asserted that a post-mortem examination had been made without the consent of the parents.

It was alleged that the Coroner for Middlesex, being, as you know, a member of the Committee, endeavoured to prevent an inquest from being held on the deceased.

It was insinuated that when the inquest was, in fact, about to be held, a sum of money was paid, at the instance of the Committee, in order to procure its suppression.

It was pretended that the operating table was, by order of the Committee, used also for dissections.

And it was declared that the Committee had invited Mr. Gay to return to the Hospital.

A few words will show how completely and absolutely every one of these charges was proved to be unfounded.

The alleged neglect and ill-treatment of the patient had no other foundation than the assertions of a female unconnected with the Hospital, but who was permitted to attend upon him at his parent's request, and of another person who had been for a short time employed in the Hospital. Their testimony was contradicted, on oath, point by point, by every one of the parties implicated. The contradiction was further sustained by the evidence, on oath, of several patients of respectable character, present in the ward with the child, all of whom also distinctly swore that the alleged ill-treatment could not have occurred without their cognizance. Moreover, the chief accusing witness was proved, on the oath of the summoning officer of the court, to have confessed the falsehood of her charges with bitter contrition; and subsequently, when she herself was again placed before the Coroner, she repeated this confession with respect to the most important points.

Evidence on oath was given that the father of the child sanctioned a post-morten examination,

The Coroners for Middlesex entirely disposed of the charge that they had thrown obstacles in the way of an inquest. Mr. Wakley, having felt that his connexion with the Hospital rendered it undesirable that he should himself preside over the inquiry, requested his colleague, Mr. Baker, who was entirely unconnected with the Hospital, to act in his place; and that gentleman, in the exercise of his discretion, after the father of the child had withdrawn his application, declined the first inquest.

The accusation that a sum of money was paid at the instance of the Committee, or of some person acting under their influence, to procure the suppression of the inquiry, is one of those scandalous fabrications which unfortunately find too ready an acceptance in certain minds. It is a pure invention. It arose from the fact, much lamented by the Committee, that a solicitor, retained by $\mathrm{Mr}$. Cooke to watch the case on his behalf, paid the attorney representing the parents of the deceased child a sum of money to withdraw the application. Both these gentlemen liave narrated on oath the whole transaction. Mr. Cooke's solicitor declared he made the payment in question of his own mere motion, without any anthority to do so, either from his own client or from the Committee; and the latter body, from their very first knowledge of it, deplored and repudiated the whole affair.

The allegation respecting the identity of the operating and dissecting tables came, the Committee regret to say, from the mouth of Mr. Gay, late surgeon to the Institution. A visit to the Hospital, which is always open to public inspection, will satisfy any one of the groundlessness of the accusation. The tables in question are not only distinct, but are, and always have been, placed in separate apartments. In October last, the following resolution passed by the Committee was sent to Mr. Gay and the other surgeons of the Hospital: -

Resolved, - "That a commodious theatre having been erected in the Hospital, the chief operations in surgery be henceforth performed therein, except in cases where the removal of patients would be attended with danger."

In the theatre referred to is a lecture table and the operating table. The latter was in the possession of the Hospital, and had been many times used by Mr. Gay, long previous to the existence of the theatre. This table, from its peculiar construction, is totally inapplicable for dissections, and has never been so used. If therefore Mr. Gay ever performed surgical operations on a dissecting table, he must have so operated by his own choice and not from necessity.

The Committee most unequivocally deny that any overtures were ever made to Mr. Gay by them, or with their knowledge or sanction, to induce him to resume his position at the Hospital.

Such were the only tangible charges made against the Managing Committee at the late inquiry, and complete and ample was their refutation. In point of fact, there was originally no reason for holding an inquest in the case at all, more than in any other instance where an operation has terminated fatally. "The manner in which it was "got up" may be briefly noticed - the facts were established on oath.

The operation took place on the 13th of April, and the child died on the 16th. Three weeks after the death, and not till then, the Coroner was first applied to.

On the 22nd of April, Mr. Gay, already mentioned, who had repeatedly declared "he would ruin the hospital," con. sulted an attorney. He had heard, he said, in general terms, that some operation at the Royal Free Hospital had terminated fatally. He instructed the solicitor to "furrage out," as he expressed it, the circumstances of the case. This gentleman fulfilled his client's desire, and applied to the parents of the child. An inquest was demanded, and appointed to take place. Mr. Gay desired his attorney to retain counsel, advanced him the fees for that purpose, and instructed him also to reject all terms of compromise.

But as the inquest approached, and it became probable that the secrecy which had so far shrouded Mr. Gay's interference would be at an end, that gentleman appears to have become alarmed, and expressed a wish that the proceedings should cease. His attorney replied, it is too late; "the parents expect to make some money by the case." However, the attorney took the money of Mr. Cooke's solicitor; from that sum he reimbursed Mr. Gay, and divided the remainder between him. self and the parents. The latter thereupon signed a declaration that they were satisfied, withdrew their application to the coroner, and the matter was considered to be at an end.

The Committee conceire it needless to trace the subsequent intrigues which led to its revival. 
Such are the facts which first came to the knowledge of the Committee from the evidence on oath of Mr. Gay and the two solicitors at the inquest. Comment is superfluons. It is only too evident. that for the purpose of dimaging the management of the Hospital, a discarded officer (Mr. Gay) has deliberately attacked the professional character of his successor; and that with this view a casualty, such as might have occurred to the most experienced operator, has been attempted to be exaggerated into a grave default of skill, reflecting upon all concerned in the appointment of the surgeon whose competence was thus maliciously and unworthily assailed.

The Committee have already niarked their sense of the injustice of the imputation by requesting Mr. Cooke to withdraw his letter of resignation. In so acting, the Committee hope and consider that they have dome no more than their duty to the Hospital, to the medical profession, and to the public at large. To the Hospital, becanse the efficiency of the medical staff must depend in no slight degree on the support afforded to it against unjust attacks. To the profession, because the Committee refuse to acknowledge a single failure in an opera tion as a proof of general incompetency. To the public, and especially to the poor, by protesting against a verdict which must tend to unnerve the hands of all operators, their colleagues and assistants, and to deprive hospital patients of one great security, the confidence of their medical officers that a casnalty will not be treated as a crime.

In conclusion, your Committee would state that there is nothing which they so much desire in all that relates to the management of the institution as publicity. The Royal Free Hospital, at all seasonable hours, is open to public inspection, and the meetings of the Weekly Board are open to all Governors.

Having to the best of their ability endeavoured to uphold and extend the usefulness of the institution, your Committee with much confidence make this appeal to the public. As for the charity itself, and its claims to undiminished public patronage for the future, it is only necessary to refer to the past - to its twenty-six years' career of public beneficence-to the number of suffering human beings whose sorrows have been alleviated (upwards of 460,000 since the foundation of the hospital) - to the hundreds and thousands of diseased and destitute strangers and wanderers who are annually relieved by its aid - to the large numbers who daily and weekly are partaking of its benefits-and to the fact that, amongst the medical officers and governors of the Royal Free Hospital, gentlemen are to be found who for social standing, intelligence, and philanthropy, are not surpassed in any other charitable institution throughout the country.

By order of the Committee,

Board-room, Aug.7th, 1854. T. BeALE BRowne, Chairman.

\section{Correspandence.}

"Audi alteram partem."

\section{PRACTICAL OBSERVATIONS ON CHOLERA.}

\section{To the Editor of THE LanceT.}

SIR,-Present circumstances favour the belief that the fol lowing remarks may be considered worthy the columns of THE LANCET:-

It may be confidently asserted that speculative writing on cholera has proved a failure, and that with respect to its nature and essence we are now in the same position as at the period of its first irruption. However desirable, in a scientific point of view, a knowledge of its abstract nature may be, it is no less desirable that we should acquire every certainty respecting its treatment. The latter desideratum is to be anticipated from the collation of individual experience. Personally I have to answer for a considerable share of opportunities for observing the onset and development of this formidable malady; and my present purpose is to submit the results of that experience to the consideration of my professional brethren.

We judge of causes by their apparent effects, but we cannot on all occasions associate them. Successful practice is not always founded upon established theory; neither can it be denied that more importance attaches to the consideration of the former than the latter, however specions.

To the congregation of certain symptoms we give the name typhus; to others, measles; to others, small-pox, \&c.; but we know nothing concerning the agent producing them. Just the same may be said of cholera. We believe that the poison which occasions this fearful disease emanates from certain con- ditions of matter, but beyond this we are totally ignorant. The opinion which I formed of the nature of cholera in 1832 , all subsequent experience has tended to establish - that it is a fobrile disease, occurs sporadically as well as epidemically, and is essentially contagious. The rationale of treatment then adopted I have had no reason to relinquish. Experience has induced variety in the means; but the purpose--the expulsion or counteraction of the poison-constitutes the main object of niy endearours to this day. The present alarming outbreak of the disease in this town has supplied the opportunity for so testing the practice as to warrant its recommendation to the profession.

It is a serious question for the medical profession to determine whether the premonitory diarrhoea of cholera should be indiseriminately arrested; and it becomes no less an important public inquiry, seeing the universal administration of what are called "astringents," from the comfortable ad libitum brandy and water to the most popular quack specifies. In the belief that the romiting and purging, so characteristic of cholera, do not constitute the disecse, but are simply an effort of nature to throw off the poison, I should as soon think of trying to arrest these indiscriminately by astringents as to suppress the skin eruption in measles, small-pox, \&c. In all cases of bowel irritation, during the prevalence or apprehension of cholera, I prescribe castor oil, combined with any of the preparations of ammonic. In every stage of real cholera, from the first onset of diarrhoen to the very verge of collapse, I give either castor oil and oil of turpentine, or the latter with yeast. I never saw an instance where immediate relief to the symptoms did not follow, and scarcely one where the stage of collapse supervened -nay, even the last fatal prostration has in some remarkable instances during the present eridemic been changed into reaction and recovery by the turpentine and yeast. But from a knowledge of the potent effects of yeast in malignant typhus, small-pox, \&c., I was first induced to try it in cholera, combined with the turpentine; and certainly, if fresh brewer's yeast could always be obtained, $I$ should use no other remedy than the following combination:-Yeast, a tablespoonful; oil of turpentine, a teaspoonful; cold water or barley-water, two tablespoonfuls: the dose to be repeated every second, third, or fourth hour, according to circumstances

Pressing engagements render these observations desultory and imperfect; but under more favourable circumstances I may, ere long, be enabled to bring further evidence in support of the above plan of treatment.

I am, Sir, yours very faithfully,

Middlesbro'-on-Tees, Aug. 185t: L. F. Crumarax.

\section{A SHADOW OF A RATIONAL TREATMENT OF CHOLERA.}

To the Editor of THE LANCET.

SIR,- Nothing is more striking, in the history of malignant cholera and its treatment (?), than the great number of powerful medicines, of entirely opposite actions, which have been employed with asserted benefit. Very large and very small doses of calomel, common salt, tartar emetic, phosphorus, creasote, iced water, sulphuric acid, opium, soda and salines, transfusion, sulphur, nitrate of silver, acetate of lead, sulphate of copper, purgative doses of castor oil, are some of the most vaunted methods of opposing the dread pestilence which has now, for the third time, invaded us. To my mind the incongruity of the medicines administered, and the similar results said to be derived from all of them, show conclusively that no treatment hitherto proposed has more than the slightest influence in checking real Asiatic cholera. As regards simple diarrhœa, relief may be obtained by very different, and apparently opposite, plans of treatment; but, as regards genuine cholera, our chaotic therapentics show but very poor results.

The profuse serous loss from the bowels is evidently the thing which kills. The collapse is not much, if it is anything more than the exhaustion following upon what may be called a profuse and continued serous hæmorrhage. The ponring out of the serum sanguinis by the stomach and intestines, is just as though the great arterial trunks of the coliac axis and the superior and inferior mesenterics, were wounded so as to allow the escape of the serum of the blood to that point of exhaustion beyond which restoration is impossible.

During the profuse serous intestimal flow of cholera, after it has fairly set in, no medicines are of any avail. The bowel is as if clead! Some preposterously give castor-oil to "clear out" the bowel already flooding forth, not only its own contents, but the serum of the blood. Others give dilute sulphuric acid as an astringent. It seems in the one case like 